\title{
JAK 2V617F Mutation: Frequency and Relation to Clinical and Laboratory Features of BCR-ABL Negative Myeloproliferative Diseases
}

\author{
Gul ILHAN, Sema KARAKUS, Feride I. SAHIN \\ Baskent University Faculty of Medicine, Department of Hematology \\ Baskent University Faculty of Medicine, Department of Medical Genetic, Ankara, TURKEY
}

\begin{abstract}
In this study, we planned to investigate frequency of the JAK2 V617F mutation and it's relation with clinical and laboratory findings of BCR-ABL negative myeloproliferative diseases (MPD) which consist of polycythemia vera (PV), essential thrombocythemia (ET) and idiopathic myelofibrosis (IMF). Totally 65 patients were included in the study which composed of 28 (43.1 \%) PV, 29 (44 \%) ET and

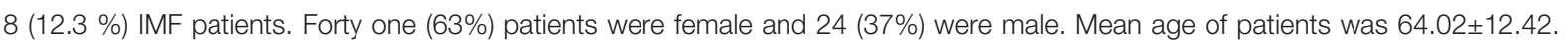
Frequency of the JAK2V617F mutation was found in 25 (89.3\%) of PV, 18 (62.1\%) of ET and 2 (25\%) of IMF patients. We found no difference in gender and frequency of thrombosis, constitutional symptoms, pruritus, hemorrhage, splenomegaly, bone marrow fibrosis, cytoreductive treatment requirement, arterial/venous thrombosis between JAK2 V617F mutated and unmutated PV and ET and IMF patients. When compared homozygous and heterozygous JAK2 V617F mutated PV and ET patients according to these variables, there was no significant difference. There were no statistically significant difference in Hemoglobin $(\mathrm{Hb})$, hematocrit (HCT), leukocyte, lactate dehidrogenase (LDH), EPO and ferritin levels between JAK2 V617F mutated and unmutated PV and ET patients. HCT levels and leukocyte counts were significantly higher in JAK2 V617F mutated than unmutated IMF patients $(p=0.046, p=0.046)$. Other variables were not found different. Comprehensive prospective studies are necessary for determining the relationship of the JAK2 V617F mutation with clinical and laboratory findings .
\end{abstract}

Keywords: JAK2 V617F mutation, Polycythemia vera, Essential thrombocytemia, Idiopathic myelofibrosis

\section{ÖZET}

JAK 2V617F Mutasyonu: BCR-ABL Negatif Myeloproliferatif Hastalıklardaki Sıklığı, Klinik ve Laboratuar Bulgularla iliş̧kisi

Bu çalışmada, polisitemia vera (PV), esansiyel trombositemi (ET) ve idiopatik myelofibrozisten (IMF) oluşan BCR-ABL negatif myeloproliferatif hastalıklarda JAK2 V617F mutasyonunun sıklı̆ı, klinik ve laboratuar bulgularılla ilişkisini araştırmayı planladık. Çalışmaya 28 (\%43.1) PV, 29 (\%44) ET, 8 (\%12.3) IMF hastası olmak üzere toplam 65 hasta alındı. Hastaların 41'i (\%63) kadın, 24'ü (\%37) erkekti. Ortalama yaş 64.02 \pm 12.42 idi. Bu mutasyonun sıklığı, PV hastalarının 25'inde (\%89.3), ET hastalarının 18'inde (\% 62.1) ve IMF hastalarının 2'sinde (\%25) olarak bulundu. JAK2 V617F mutasyonu olan ve olmayan PV ve ET ve IMF hastaları arasında cinsiyet, tromboz sıklı̆ı, konstitüsyonel semptomlar, pruritus, hemoraji, splenomegali, kemik iliği fibrozisi, sitoredüktif tedavi intiyacı, arteriyel/venöz tromboz gelişimleri açısından bir fark bulamadık. Heterozigot ve homozigot JAK2 V617F mutasyonu olan PV ve ET hastaları, bu parametreler açısından karşılaştııılı̆ğında, anlamlı bir fark yoktu ( $p>0.05)$.

Anahtar Kelimeler: JAK V617F Mutasyonu, Polistemia vera, Esansiyel trombositemi, İdiopatik myelofibrozis 
JAK2 V617F mutasyonu olan ve olmayan PV ve ET hastaları arasında hemoglobin (Hb), hematokrit (HCT), lökosit, laktik dehidrogenaz (LDH), EPO ve ferritin düzeyleri açısından istatistiksel bir fark yoktu (p>0.05). Hematokrit düzeyleri ve lökosit sayıları JAK2 V617F mutasyonu olan IMF hastalarında mutasyon olmayanlara göre belirgin olarak daha yüksekti $(p=0.03 p=0.01)$. Diğer parametreler farklı bulunmadı. Klinik ve laboratuvar bulgularla JAK2 V617F mutasyonu arasındaki ilişkiyi tanımlamak için daha geniş kapsamIı prospektif çalışmalar gereklidir.

Anahtar Kelimeler: JAK2 V617F mutasyonu, Polisitemia vera, Esansiyel trombositemi, İdiopatik myelofibrozis

\section{INTRODUCTION}

Myeloproliferative diseases (MPD) are heterogenous, clonal group of disease which occur in response to cytokines independently. In MPD, hematopoietic cells are hypersensitive to cytokines and they perform uncontrolled proliferation. Since 2008, World Health Organisation (WHO) has named this group as myeloproliferative neoplasms (MPN). MPN are chronic myelogenous leukemia (CML), BCR-ABL positive, chronic neutrophilic leukemia, polycythemia vera (PV), idiopathic myelofibrosis (IMF), essential thrombocythemia (ET), chronic eosinophilic leukemia, not otherwise specified, mastocytosis and myeloproliferative neoplasms, unclassifiable. ${ }^{1}$

Janus Kinase 2 (JAK2) is a non receptor tyrosine kinase molecule which plays an important role in lifecycles of hematopoietic progenitor cells. JAK2 contributes to synthesis of erytropoetin (EPO), thrombopoetin, GM-GSF receptors and serves as tyrosine kinase for them. After an acquired point mutation of JAK2, resulting in valine to phenylalanine substitution at the 617 amino acid, JAK2 escapes from otoregulator system and becomes active without physiological signal. JAK2 gene is on 9th chromosome and this point mutation was identified in BCR-ABL negative MPD in 2005..$^{2-6}$ According to the studies, JAK2 V617F mutation is seen $97 \%$ of PV, $57 \%$ of ET and $50 \%$ of IMF. ${ }^{3}$ In addition, JAK2 V617F mutation has been identified in atypical MPD, myelodysplastic syndrome, and erytroleukemia. For this reason, this mutation is not a specific genetic marker like BCR-ABL translocation used in CML diagnosis. But recently, it has been started to use in diagnostic algoritm especially for PV. Four different mutation were identified in exon 12 area of JAK2 gene in patients with JAK2 V617F negative PV but not in patients with ET. Patients with exon 12 mutation generally have low EPO levels and more dominant erytroid lineage than other series in bone marrow. In a study, exon 12 mutation was identified in 4 of 20 patients with PV and idiopathic erytrocytosis and there were no difference in age, gender, leukocyte count between two groups. ${ }^{5}$ But patients with exon 12 mutation had higher $\mathrm{Hb}$ and lower platelet count than patients without the mutation. There were no difference in thrombosis development and myelofibrotic transformation between two groups. ${ }^{5}$ Another mutation identified in MPD is MPL mutation (MPLW515L). MPL is described in juxtamembran region of thrombopoetin receptor in IMF and rarely ET but not in PV? This mutation was seen 5\% in IMF patients and these patients had reported to have lower Hb levels and higher transfusion requirement. MPL mutation was seen $1 \%$ of ET patients and it's clinical importance is not clear. Patients with JAK2 mutation was reported to have higher $\mathrm{Hb}$, leukocyte counts and more cellular bone marrow. ${ }^{8}$ While some studies showed increase risk of thrombosis in JAK2 positive ET patients ${ }^{4,9,10,11}$, some studies showed no relationship between JAK2 mutation and thrombosis in ET patients. ${ }^{12,13,14}$ Thrombosis, an important morbidity and mortality cause in MPD, was found related to neutrophile activation on platelet-neutrophile complexes. ${ }^{10,15-19}$ JAK 2 mutation was reported to provide a convenient situation for formation of platelet-neutrophile agregates ${ }^{10}$ and this can explain why hydroxyurea is more effective than anagrelide in thrombosis prevention. ${ }^{15,19}$ Another study with 397 PV patients reported that thrombosis risk was not related to mutation prophile (wild type, heterozygous or homozygous) ${ }^{20}$ Primignani and coworkers showed that JAK2 V617F mutation was found in 35\% of 73 patients with portal vein thrombosis and in $40 \%$ of 20 patients with Budd Chiari syndrome. ${ }^{19}$ Boissinot and coworkers found JAK2V617F mutation in $58 \%$ of patients with idiopathic Budd Chiari syndrome. ${ }^{21}$ JAK2 V617F was seen in 38$43 \%$ of splancnic vein thrombosis with normal or 
low blood counts and in $18-37 \%$ of portal vein thrombosis. ${ }^{22}$ In another study, JAK2 mutation was found in $74 \%$ of 19 idiopathic portal or hepatic vein thrombosis and JAK2 mutation was reported as a valuable genetic marker in latent MPD diagnosis. ${ }^{23}$ In a study, ET patients with JAK2 V617F mutation were found to have higher $\mathrm{Hb}$, neutrophile levels than patients without the mutation. ${ }^{24}$ In addition, ET patients with JAK2 mutation were reported to have increased bone marrow erytropoesis and granulopoesis, more venous thrombosis, lower erytropoetin and ferritin levels and more frequent polcytemic transformation than patients without the mutation. ${ }^{15}$ ET patients with JAK2 V617F mutation were reported to have lower platelet counts and lower hydroxyurea dose requirement for controlling of platelet level. Campbell et al thought that JAK2 mutation positive ET was fenotypical similar with PV and these diseases could be accepted as continuation of each other. ${ }^{5}$ Another study reported that homozygous JAK2 V617F mutated PV patients had higher hemoglobin and neutrophile counts, more tendency to pruritus and bone marrow fibrosis than unmutated or heterozygous mutated PV patients. ${ }^{24}$ But thrombosis or hemorrhage frequency, cytogenetic abnormalities, transformation to myelofibrosis and acute leukemia were similar in JAK2 unmutated, heterozygous or homozygous mutated PV patients. ${ }^{24}$ One of the recent studies reported that increase in mutation degree resulted in increase in the frequency of thrombosis, leukocytosis and splenomegaly. ${ }^{24}$ Generalised pruritus was found more frequent in homozygous JAK2 mutated PV patients than unmutated or heterozygous mutated PV patients..$^{24,25}$

There are few data about relation of JAK2 mutation to leukemic transformation. Kraloyics et al were found no relationship for JAK2 mutation and leukemic transformation in 244 MPD patients. ${ }^{4}$ Jelinek and friends showed low JAK2 mutation incidence of secondary AML in IMF and PV patients. ${ }^{25}$

In a retrospective study with $63 \mathrm{PV}$ patients performed by Tefferi et al, there was found no clinical difference in JAK2 mutated and unmutated PV patients but some differences in homozygous and heterozygous mutated patients. Homozygous PV patients had higher $\mathrm{Hb}$ levels and more frequent bone marrow fibrosis. ${ }^{23}$
JAK2 V617F mutation in IMF was found in relationship with high leukocyte count, poor prognosis and agressive disease. ${ }^{26}$

\section{PATIENTS AND METHODS}

This study was approved by Baskent University Instutional Review Board and Ethics Committee. After getting informed consent from 28 PV, 29 ET and 8 IMF patients, genomic DNA isolation was performed by using High Pure Isolation Kit (Roche Molecular Biochemicals, Mannheim, Germany) and spin colon method. In order to identify JAK2 V617F point mutation, DNA samples were added into mixture of PCR which prepared with primary probe set diluated specific to reaction and "LightCycler Fast Start DNA Master Hybridization Probe" (Roche Molecular Biochemicals, Mannheim, Germany) kit content.

Analysis were performed with Light Cycler 2.0 analysis program. Genotype was identified according to "Melting Curves". Melting curves were made after determining tm degrees $53^{\circ} \mathrm{C}$ for mutant serie and $62^{\circ} \mathrm{C}$ for wild type (naturel type). A peak seen only at $62^{\circ} \mathrm{C}$, only at $53^{\circ} \mathrm{C}$ and at both tm accepted as wild type, homozygous mutant and heterozygous mutant respectively.

We used mean value \pm standart deviation for numeric data and percent/ratio for categorical data of demographic and disease related features. We investigated relation of JAK2 V617F mutation to $\mathrm{Hb}$, HCT, platelet, leukocyte, ferritin, LDH and erytropoietin levels, gender, splenomegaly, constitutional symptoms, pruritus, bone marrow fibrosis, bone marrow cellularity, thrombosis, hemorrhage, cytoreductive therapy requirement by using univariate analysis. Univariate analysis performed by Ki-square and Mann Whitney U tests SPSS 10 for Windows (Statistical Package for the Social Sciences 10) (SPSS Inc. Chicago, A.B.D).

\section{RESULTS}

Sixty five patients were included in the study. Mean age of the patients was $64.02 \pm 12.42$. Forty one patients $(63 \%)$ were female, 24 patients $(37 \%)$ were male. Twenty eight patients (43\%) were PV, 29 $(44.6 \%)$ were ET and 8 (12.3\%) were IMF. JAK2 
Table 1. Frequency of JAK2 V617F mutation in myeloproliferative diseases

\begin{tabular}{|llll|}
\hline & \multicolumn{3}{c|}{ JAK2 MUTATION } \\
\cline { 2 - 4 } & Positive $(n, \%)$ & Negative $(n, \%)$ & Total $(n, \%)$ \\
\hline PV & $25(89.3 \%)$ & $3(10.7 \%)$ & $28(100 \%)$ \\
ET & $18(62.1 \%)$ & $11(37.9 \%)$ & $29(100 \%)$ \\
IMF & $2(25 \%)$ & $6(75 \%)$ & $8(100 \%)$ \\
\hline
\end{tabular}

V617F is positive in $25(89.3 \%)$ of $\mathrm{PV}, 18(62.1 \%)$ of ET and 2 (25\%) of IMF patients (Table 1).

We compared JAK2 V617F mutated and unmutated $28 \mathrm{PV}$ patients in terms of gender, frequency of thrombosis, constitutional symptoms (weakness, fever, night sweat, weight loss), pruritus, hemorrhage, splenomegaly, bone marrow fibrosis, bone marrow cellularity, requirement of cytoreductive treatment and we found no difference between two groups ( $>>0.05)$. All these variables are not statistically different between homozygous and heterozygous JAK2 V617F mutated PV patients. There was no difference in $\mathrm{Hb}, \mathrm{HCT}$, leukocyte, $\mathrm{LDH}$, EPO, uric acit, ferritin levels between JAK2 V617F mutated and unmutated PV patients ( $\mathrm{p}>0.05$ ). There were 11 arterial and 2 venous thrombosis in PV patients and found no difference in frequency of thrombosis between JAK2 V617F mutated and unmutated PV patients ( $\mathrm{p}>0.05$ ).

In $29 \mathrm{ET}$ patients, there were no difference in terms of gender, thrombosis frequency, constitutional symptoms, pruritus, hemorrhage, splenomegaly, bone marrow fibrosis, bone marrow cellularity and requirement of cytoreductive treatment between JAK2 mutated and unmutated patients ( $p>0.05$ ). All these variables were similar between homozygous and heterozygous JAK2 V617F mutated ET patients. Two groups were compared in terms of $\mathrm{Hb}, \mathrm{HCT}$, leukocyte, LDH, EPO, uric acit, ferritin levels and found no difference ( $\mathrm{p}>0.05$ ). There were 8 arterial and 1 venous thrombosis in ET patients. Frequecy of arterial and venous thrombosis were similar between JAK2 V617F mutated and unmutated ET patients.

JAK2 mutated and unmutated 8 IMF patients compared in points of gender, frequency of thrombosis, constitutional symptoms, pruritus, hemorrhage, splenomegaly, bone marrow fibrosis, cytoreductive treatment requirement and bone marrow cellularity and found no difference ( $\mathrm{p}>0.05)$. JAK2 mutated and unmutated IMF patients were compared according to $\mathrm{Hb}, \mathrm{HCT}$, leukocyte, $\mathrm{LDH}$, EPO, uric acit, ferritin levels. HCT and leukocyte levels were found higher in JAK2 V617F mutated IMF patients

Table 2. Relationship between JAK2V617F mutation and laboratory variables in IMF patients.

\begin{tabular}{|llll|}
\hline & \multicolumn{3}{c|}{ JAK2 MUTATION } \\
\cline { 2 - 4 } & Positive (median) & Negative (median) & P value \\
\hline Hemoglobin $(\mathrm{g} / \mathrm{dll})$ & 12.5 & 9,04 & 0.09 \\
Hematocrit $(\%)$ & 38.7 & 26.05 & 0.046 \\
Leukocyte $\left(/ \mathrm{mm}^{3}\right)$ & 30550 & 7235 & 0,046 \\
platelet $\left(/ \mathrm{mm}^{3}\right)$ & 305500 & 191000 & 0.505 \\
LDH $\left(\mathrm{IU} / \mathrm{ml}^{3}\right)$ & 274.5 & 303 & 0.182 \\
Üric acit $(\mathrm{mg} / \mathrm{dl})$ & 6.4 & 7.3 & 1 \\
\hline
\end{tabular}


than unmutated patients $(\mathrm{p}=0.046 \mathrm{p}=0.046)$ (Table-2). Other variables were similar in two groups $(\mathrm{p}>0.05)$.

\section{DISCUSSION}

We aimed to investigate frequency of JAK2 V617F mutation and relation to clinical and laboratory findings of patients with PV, ET and IMF. The limitation of our study is smaller patient ( especially in IMF patients) population than literature.

Frequency of MPD increases with age and median age is $60 .{ }^{3}$ Similarly, mean age of patients in our study was $64.02 \pm 12.42$ (19-87). JAK2 V617F mutation was identified $97 \%$ in PV, $57 \%$ in ET and $50 \%$ in IMF patients (4). In our study, we found the mutation $89.3 \%$ in PV, $62.1 \%$ in ET and $25 \%$ in IMF patients.

We didn't find any difference in frequency of arterial and venous thrombosis in PV patients ( $\mathrm{p}>0.05)$. There are insufficient data about this in studies investigating arterial and venous thrombosis in PV patients. ${ }^{11,16,27,28}$

Frequency of homozygous JAK2 V617F mutation in PV is higher than in ET patients. In PV patients frequency of homozygous JAK2 V617F mutation is about $30 \%$ and the mutation seems to be related to policytemic phenotype. ${ }^{29}$ In a study with $63 \mathrm{PV}$ patients, $\mathrm{Hb}$, leukocyte, platelet count, pruritus, myelofibrosis and acute leukemic transformation, hemorrhage/thrombosis frequency were compared in homozygous and heterozygous JAK2 V617F mutated patients. Hb level, pruritus and frequency of myelofibrosis transformation were higher in homozygous mutated patients than heterozygous mutated patients. Thrombosis and hemorrhage frequencies were similar in homozygous mutated and heterozygous mutated patients..$^{23}$ In our study, frequency of homozygous JAK2 V617F mutation was $9.1 \%$ and it was lower than expected. Homozygous and heterozygous patients were not different in point of thrombosis, constitutional symptoms, pruritus, hemorrhage, splenomegaly, frequency of bone marrow fibrosis, bone marrow cellularity and requirement of cytoreductive treatment.

In a study with 150 ET patients, JAK2V617F mutated patients were reported to have higher median age, leukocyte count, platelet count and frequency of transformation to PV than unmutated patients. There were no difference according to splenomegaly, cytogenetic abnormalities, vasomotor symptoms, frequency of thrombosis and hemorrhage, requirement of cytoreductive treatment and median survival between two group..$^{30}$ In a prospective study conducted with 806 ET patients, JAK2 V617F mutated patients had higher Hb, leukocyte counts, more erytropoesis and granulopoesis in bone marrow, more frequent venous thrombosis and polycytemic transformation, less EPO and ferritin levels than unmutated patients. In addition, this study reported that JAK2 V617F mutated patients have more benefit from hydroxyurea than anagrelid. ${ }^{5}$ Our study showed no difference in terms of frequency of thrombosis, constitutional symptoms, pruritus, hemorrhage, splenomegaly, bone marrow fibrosis, bone marrow cellularity and cytoreductive treatment, between JAK2 mutated and unmutated ET patients. In addition, Hb, HCT , leukocyte, $\mathrm{LDH}, \mathrm{EPO}$, uric acit and ferritin levels were similar in two groups.

In a study conducted with ET patients, JAK2V617F mutation was reported to be in relationship with venous thrombosis rather than arterial thrombosis. ${ }^{15} \mathrm{In}$ a recent study, 867 patients with ET wild-type, ET V617F, and 415 patients with PV showed a rate of thrombosis of $1.4 \%, 2.1 \%$, and $2.7 \%$ /patients/year. Actuarial probability of arterial and venous thrombosis in the first 5 years of diagnosis was roughly similar in the three groups. The curves of mutated ET patients diverged from wild-type, and after 10 to 15 years the ET-mutated arm approached PV..$^{31}$ In our study, frequency of arterial and venous thrombosis were found similar in JAK2 V617F mutated and unmutated ET patients.

In GIMEMA MPD Group's study conducted with 639 ET patients, JAK2 V617F mutation was found heterozygous in $57.6 \%$, homozygous in $2.2 \%$ and negative $40.2 \%$ of patients. This study reported that, JAK2 V617F homozygous mutated patients had increased erytropoesis and granulopoesis and lower platelet count than unmutated and heterozygous mutated patients. In addition, homozygous mutated ET patients were found to have higher incidence of splenomegaly and increased requirement of cytoreductive treatment. Homozygous mutated ET patients were reported to have higher 
thrombosis incidence than the others. In this study JAK2 V617F mutation was found heterozygous in $67.8 \%$ and homozygous in $32.2 \%$ in 323 PV patients. Homozygous mutated PV patients were found to have increased erytropoesis, granulopoesis, higher incidence of splenomegaly, higher requirement of cytoreductive treatment, lower platelet levels and higher incidence of pruritus than heterozygous mutated PV patients. There were no difference in point of frequency of thrombosis. ${ }^{32}$ In another study, JAK2 V617F mutation occurs in a homozygous state in $25 \%$ to $30 \%$ of patients with PV and $2 \%$ to $4 \%$ with ET. 118 homozygous patients (104 PV, 14 ET) were older, displayed a higher leukocyte count and hematocrit value at diagnosis and presented larger spleen size. Homozygosity associated with more frequent evolution into secondary myelofibrosis in both PV and ET. Homozygous ET patients displayed a significantly higher risk of cardiovascular events..$^{24}$ In our study, frequency of thrombosis, constitutional symptoms, pruritus, frequency of hemorrhage, splenomegaly, bone marrow fibrosis, bone marrow cellularity and requirement of cytoreductive treatment were not significantly different between homozygous and heterozygous mutated patients.

In a study conducted with 152 IMF patients, JAK2 V617F mutated and unmutated patients were not different in terms of age, gender, spleen size, $\mathrm{Hb}$, LDH and platelet levels. But JAK2 V617F mutated patients were found to have higher leukocyte and neutrophile counts than unmutated patients. In addition, JAK2 V617F mutated patients were found to have rarer need of transfusion but less survival than unmutated patients. ${ }^{33}$ On the other hand, Tefferi and coworkers reported JAK2 V617F have no effect on survival and leukemic transformation but to have related with thrombosis. ${ }^{34}$ In the Barosi and coworkers' study with 304 IMF patients, JAK2 V617F mutation was found in $63.5 \%$ of patients. In addition, JAK2 V617F mutated patients were found to have higher $\mathrm{Hb}$, leukocyte and platelet counts and more frequent pruritus than unmutated patients. ${ }^{35}$ A recent study showed that a low JAK2V617F allele burden at diagnosis is associated with a myelodepletive rather than myeloproliferative phenotype and associated with shortened survival in PMF patients. ${ }^{36}$ In our study, we found JAK2 V617F mutated IMF patients to have higher
HCT and leukocyte levels than unmutated IMF patients. There were no significant difference in point of $\mathrm{Hb}$, leukocyte counts, $\mathrm{LDH}, \mathrm{EPO}$, uric acit and ferritin levels between JAK2 V617F mutated and unmutated IMF patients. Frequency of thrombosis, constitutional symptoms, pruritus, hemorrhage, bone marrow cellularity and requirement of cytoreductive treatment were not different between JAK2 V617F mutated and unmutated IMF patients. Difference of these results from literature findings may be related to smaller patient population of IMF. In a study conducted with 6 IMF patients, relation of JAK2 V617F mutation to thrombosis is reported to be unclear. ${ }^{26}$

JAK2 Exon 12 mutation was reported 3-4\% in PV patients. In a comprehensive study compared 409 patients with idiopathic erytrocytosis and 719 PV patients, frequency of JAK2 exon 12 mutation was found $3.7 \%$. These patients were younger than JAK2 V617F mutated PV patients and have dominance of female gender. In addition, higher HCT, lower EPO levels, lower platelet and leukocyte counts in JAK2 exon 12 mutated PV patients than JAK2 V617F mutated patients. ${ }^{6}$ In our study, JAK2 V617F mutation was negative in $10.7 \%$ of PV patients and we couldn't investigate JAK2 Exon 12 mutation in these PV patients.

In this study, we investigated JAK2 V617F mutation frequency and it's relation to clinical and laboratory findings of BCR-ABL negative MPD patients. More comprehensive prospective studies are needed to show prognostic value of the mutation and relation to clinical and laboratory variables .

\section{REFERENCES}

1. Vardiman JW, Thiele J, Arber DA, et al. The 2008 revision of the World Health Organization (WHO) classification of myeloid neoplasms and acute leukemia: rationale and important changes. Blood 114: 937-951, 2009.

2. Sandberg EM, Wallace TA, Godeny MD, et al. JAK2 tyrosine kinase: a true JAK of all trades? Cell Biochem Biophys 41: 207-232, 2004.

3. Campbell PJ, Green AR. The myeloproliferative disorders. N Engl J Med 335: 2452-2466, 2006.

UHOD Number: 2 Volume: 22 Year: 2012 
4. Kralovics T, Passamonti F, Buser AS, et al. A gain-of function mutation of JAK2 in myeloproliferative disorders. N Engl J Med 351: 1779-1790, 2005.

5. Campbell PJ, Scott LM, Buck G, et al. Definition of subtypes of essential thrombocythemia and relation to polycythemia vera based on JAK2 V617F mutation status: a prospective study. Lancet 366: 1945-1953, 2005.

6. Schnittger S, Bacher U, Haferlach C, et al. Detection of JAK2 exon 12 muatations in 15 patients with JAK2V617F negative policythemia vera. Haematologica 94: 414-418, 2009.

7. Beer PA, Campbell PJ, Scott LM, et al. MPL mutations in myeloproliferative disorders: analysis of the PT-1 cohort. Blood 112: 141-149, 2008.

8. Pardanani AD, Levine RL, Lasho T. MPL515 mutations in myeloproliferative and other myeloid disorders: a study of 1182 patients. Blood 108: 3472-3476, 2006.

9. Ohyashiki K, Aota Y, Akahane D, et al. JAK2(V617F) mutational status as determined by semiquantitative sequence-specific primer-single molecule fluorescence detection assay is linked to clinical features in chronic myeloproliferative disorders. Leukemia 21: 10971099, 2007.

10. Cheung B, Radia D, Pantedelis $P$, et al. The presence of the JAK2 V617F mutation is associated with a higher haemoglobin and increased risk of thrombosis in essential thrombocythemia. $\mathrm{Br} J$ Haematol 132: 244250, 2005.

11. Finazzi G, Rambaldi A, Guerini $V$, et al. Risk of thrombosis in patients with essential thrombocythemia and polycythemia vera according to JAK2 V617F mutation status. Haematologica 92: 135-136, 2007.

12. Wolanskyj AP, Lasho TL, Schwager SM, et al. JAK2 mutation in essential thrombocythaemia: clinical associations and long-term prognostic relevance. $\mathrm{Br} \mathrm{J} \mathrm{Ha}$ ematol 131: 208-213, 2005.

13. Tefferi A. Essential thrombocythemia: scientific advances and current practice. Curr Opin Hematol 13: 9398, 2006.

14. Antonioli E, Guglielmelli $P$, Pancrazzi $A$, et al. Clinical implications of the JAK V617F mutation in essential thrombocythemia. Leukemia 19: 1847-1849, 2005.

15. Jensen MK, De Nully Brown P, et al. Increased circulating thrombocyte leukocyte aggregates in myeloproliferative disorders is correlated to previous thrombosis, thrombocyte activation and thrombocyte count. Eur J Haematol 66: 143-151, 2001.

16. Falanga $A$, Marchetti $M$, Vignoli $A$, et al. Leukocyte-thrombocyte interaction in patients with essential thrombocythemia and polycythemia vera. Exp Hematol 33: 523-530, 2005.

17. Arellano-Rodrigo E, Alvarez-Larran A, Reverter JC, et al. Increased thrombocyte and leukocyte activation as contributing mechanisms for thrombosis in essential thrombocythemia and correlation with the JAK2 mutational status. Haematologica 91: 169-175, 2006.
18. Maugeri N, Giordano G, Petrilli MP, et al. Inhibition of tissue factor expression by hydroxyurea in polymorphonuclear leukocytes from patients with myeloproliferative disorders: a new effect for an old drug? J Thromb Haemost 4: 2593-2598, 2006.

19. Primignani M, Barosi G, Bergamaschi G, et al. Role of the JAK2 mutation in the diagnosis of chronic myeloproliferative disorders in splanchnic vein thrombosis. Hepatology 44:1528-1534, 2006.

20. De Stefano V, Fiorini A, Rossi E, et al. High prevalence of the JAK2 V617F mutation in patients with extra hepatic portal vein thrombosis. Hepatology 45: $831-$ 833, 2007.

21. Boissinot $M$, Lippert E, Girodon F, et al. Latent myeloproliferative disorder revealed by the JAK2V617F mutation and endogenous megakaryocytic colonies in patients with splanchnic vein thrombosis. Blood 108: 3223-3224, 2006.

22. Goulding $C$, Uttenthal $B$, Foronı $L$, et al. The JAK2 V617F tyrosine kinase mutation identifies clinically latent myeloproliferative disorders in patients presenting with hepatic or portal vein thrombosis. Int J Hematol 30: 415-419, 2008.

23. Tefferi A, Lasho TL, Schwager SM, et al. The clinical phenotype of wild-type, heterozygous, and homozygous JAK2V617F in polycythemia vera. Cancer 106: 631-635, 2006.

24. Vannucchi AM, Antonioli E, Guglielmelli P, et al. Clinical profile of homozygous JAK2V617F mutation in patients with polycythemia vera or essential thrombocythemia. Blood 110: 840-846, 2007.

25. Jelinek J, Oki Y, Gharibyan V, et al. JAK2 mutation $1849 \mathrm{~g}>\mathrm{t}$ is rare in acute leukemias but can be found in $\mathrm{cmml}$, Philadelphia chromosome-negative $\mathrm{cml}$, and megakaryocytic leukemia. Blood 106: 3370-3373, 2005.

26. Spivak, J. L. The chronic myeloproliferative disorders: clonality and clinical heterogeneity. Semin Hematol 41: 1-5, 2004.

27. Vannucchi AM. Insights into the pathogenesis and management of thrombosis in polycythemia vera and essential thrombocythemia. Intern Emerg Med 5: 177184, 2010.

28. Finazzi G, Ruggeri M, Rodeghiero F. Efficacy and safety of long-term use of hydroxyurea in young patients with essential thrombocythemia and a high risk of thrombosis Blood 101: 3749, 2003.

29. Scott LM, Scott MA, Campbell PJ, et al. Progenitors homozygous for the V617F mutation occur in most patients with polycythemia vera, but not essential thrombocythemia. Blood 108: 2435-2437, 2006.

30. Wolanskyj AP, Lasho TL, Schwager SM, et al. JAK2 mutation in essential thrombocythaemia: clinical associations and long-term prognostic relevance. $\mathrm{Br} \mathrm{J}$ Haematol 131: 208-213, 2005. 
31. Carobbio A, Finazzi G, Antonioli E, et al. JAK2V617F allele burden and thrombosis: a direct comparison in essental thrombocythemia and polycythemia vera. Exp Hematol 37: 1016-1021, 2009.

32. Vannucchi AM, Antonioli E, Guglielmelli P, et al. Clinical profile of homozygous JAK2V617F mutation in patients with polycythemia vera or essential thrombocythemia. Blood 110: 840-846, 2007.

33. Campbell PJ, Griesshammer M, Döhner K, et al. V617F mutation in JAK2 is associated with poorer survival in idiopathic myelofibrosis. Blood 107: 20982100, 2006.

34. Tefferi A, Lasho TL, Scwager SM, et al. The JAK2 (V617F) tyrosine kinase mutation in myelofibrosis with myeloid metaplasia:lineage spesivity and clinical correlates. Br J Haematol 131: 320-328, 2005.

35. Barosi G, Bergamaschi G, Marchetti M, et al. JAK2 V617F mutational status predicts progression to larfge splenomegaly and leukemic transformation in primary myelofibrosis. Blood 110: 4030-4036, 2007.

36. Guglielmelli P, Barosi G, Specchia G, et al. Identification of patients with poorer survival in primary myelofibrosis based on the burden of JAK2V617F mutated allele. Blood 114: 1477-1483, 2009.

\section{Correspondence}

\section{Dr. Semak KARAKUŞ}

Başkent Universitesi Tıp Fakültesi

Hematoloji Bölümü

5. Sokak No. 48

Bahçelievler 06490 ANKARA / TURKEY

Tel: (+90.312) 2122912 / 208-216

Fax: (+90.312) 2154283

e-mail: semaka@ baskent-ank.edu.tr 